\title{
Features of Pedagogical Communication in Social Networks
}

\author{
Irina N. Fardeeva, Indira A. Shakirova, Elena N. Maltseva, Valentina I. Kuzmenko, Elena V. \\ Smirnova
}

\begin{abstract}
The education is enhance in computer technology very fast as in the modern life of development of technology. Accordingly, there is a need for integration between education and modern technology, which actually facilitates communication between students and teachers. Social networks have become an important component in the educational system and are widely used in most higher education institutions, as they improve traditional approaches to learning, transferring classroom education to online learning.

Social networks create new opportunities through which information is transmitted, created, mixed, constantly updated and improved by users. The boundaries of communication between teachers and students have collapsed. The students have rights to work in production and also they can create their own contents as by developing their critical thinking by social constructivism. Thus, the learning environment as a whole is affected by these new ways of knowledge provision, and teaching and learning undergo changes and take on new forms.

Taking into account these aspects, our research will be focused on the intersection between social network sites, encouraging the sense of community and opening up new opportunities for a motivating and collaborative informal learning process between teacher and students.
\end{abstract}

Key words: social networks, communication, remote education, teaching methods, information environment.

\section{INTRODUCTION}

The global spread of social networks means that communication in social networks prevails over time spent on the Internet, which means that it is very interesting.

During the learning process, a social network can become potentially an effective means of knowledge, skills and ability development. Today, an important learning skill arises: "synthesize and recognize connections and patterns", and learning is embedded in social networks, where a continuous flow of information updates, improves and enriches the previous one. This flow of knowledge is maintained, interrelated and enhanced by people. Thanks to these functions, a social network can be considered as an example of a personal learning environment, a space in which students create their own learning environment and where a user / student controls his own learning, choosing and integrating the most suitable tools for any particular type of activity [1].

This topic is not new in the research of scientists and educators. We can distinguish groups of authors who assessed

Revised Manuscript Received on November 08, 2019.

* Correspondence Author

Irina N. Fardeeva, Kazan Federal University

Indira A. Shakirova, Kazan Federal University

Elena N. Maltseva, Kazan Federal University

Valentina I. Kuzmenko, Kazan Federal University

Elena V. Smirnova, Togliatti State University, Russia

the prospects for a wide introduction to the educational process of social network use from different perspectives.

B Caci, M Cardaci, S Miceli studied the relationship between Facebook and personality traits among Italian users. Researchers analyzed the role of personality traits by various parameters of self-disclosure, Internet behavior based on a voluntary online survey evaluating personality traits and work in Facebook. It turned out that people with high extroversion and openness, as a rule, disclose a significant amount of personal information on Facebook, while the users with a high level of consciousness are less likely to do this [2].

Hershkovitz A., Elhija M. A., \& Zedan D. studied extra-curricular communication methods using WhatsApp application. Communication between students and teachers usually goes beyond class time and space. This communication can affect the academic, social and emotional development of students. Communication and learning through online social networks and student-teacher relationships make two main effects on society as a whole. First, fostering better communication between students and teachers can improve learning and teaching. Secondly, if this communication is carried out properly, students - future citizens - will learn to behave correctly in the era of digital technology [3].

Chandler P. \& Redman believe that the levels of interaction between colleagues and the wider educational community can be facilitated. The question is how to prepare new participants for professions. Scholars focus on personal learning networks, discursive learning spaces, and metacognitive thinking. Researchers offer a number of e-learning tools that could support these learning goals: training sites for teaching both large and small groups, including informal, personal and public forms of interaction [4].

Long before our days, scientists thought about the lessons of the future. Williams P. considered important events of the last 25 years at schools and teacher education in England in his works, as well as the prospects for the next 25 years. The author concludes that the current centrally controlled national system is becoming increasingly inappropriate to meet needs and will be destroyed in the future [5].

Çevik Y. D., Çelik S., \& Haşlaman T. write a lot about the role of social networks in the educational environment, as well as about their potential for professional development enhancement in education. The result of research is that scientists have proven that teachers gain positive experience using social networks to design and implement online events that are consistent with the constructivist learning paradigm [6]. 


\section{METHODS}

In accordance with the theoretical basis, the methodology of this study is based on an interpretive paradigm that considers the world as complex, dynamic and socially constructed, interpreted and experienced by people in their interactions with each other and with social systems.

Moreover, due to the novelty of research in the use of social networking technologies to support formal educational experience, a case study approach is needed. This methodology allows you to explore complex social phenomena, such as virtual communities, using a wide range of data.

To achieve our goals, we studied the examples of training in accordance with pedagogical, social and technical criteria. To increase the reliability of these results, it is necessary to adopt methodological triangulation, combining questionnaires, interactive interviews, the analysis of social networks and stimulated interview reminders, in order to study better the experience of pedagogical communication in social networks [7].

\section{RESULTS AND DISCUSSION}

Students are able to use social networks because the suggests that of communication with their lecturers, exploitation them in $56-75 \%$ of cases, reckoning on the study [8]. Draskovic, Caic, and Kustrak (2013) found that student motivation is done with interaction of student and lecturers through social networks. For that teacher has to take initiative in speaking to the student. Saylag (2013) notes that Facebook is introduce higher for such relation between lecturers as a seventy two of scholars in agreement have contacted their lecturers social media. [9]. Hurt, Moss, Bradley, Larson, and Richard Lovelace emphasize that The students aren't feel uncomfortable in the communication with their lecturers on Facebook which teachers produce new profiles to move with their students United Nations agency lack personal info by showing solely a

profile picture [10]. four-hundredth of lecturers connect with their students through Facebook, 16 PF have used it within the past, and forty first have not communicated with their students via Facebook, ninety one of scholars have not used Facebook to speak with their teachers; sixty eight didn't visit the profile of their faculty member on Facebook, and forty first indicated that they might not need their lecturers to speak with them through Facebook [11]. Erjavec noted that the majority students didn't communicate with their lecturers on social networks [12]. Hershkovitz and Forkosh-Baruch found that communication between lecturers and students on Facebook was restricted [13]. For Hank, Sugimoto, Tsou, and Pomerantz, most lecturers and students are always choose to not communicate with one another via Facebook [14]. Aaen and Dalsgaard noted that sixty fifth of scholars ne'er used social networks to

speak with their lecturers, whereas solely 100 percent of scholars used social networks to speak with their lecturers [15]. Canós-Rius and Guitert-Catases indicate that 100 percent of lecturers and students ne'er used Twitter to speak with one nine of lecturers and ninety two of scholars ne'er used
Facebook to move with one another [16]. Teachers use social networks as a tool to communicate with their students, primarily on the issues related to the organization of classes [17]. Besides, they indicate that they obtain to strengthen and support those students UN agency would like facilitate most of at some stage in social networks, yet as intervene within the cases wherever a psychosocial downside is detected through a student's profile or offer emotional support [18]. While the minority considers this inappropriate. Besides, on the one hand, there are the students who consider teacher-student communication on social networks more suitable during the training period. As an example, third and fourth year students feel softer and communicate a lot of with their lecturers through social networks as compared to initial and second year students [19]. The most in style social networks between lecturers and students are Vkontakte and WhatsApp. It has seen that student always like email to talk with teacher but they are afraid of face to face speaking with teachers. There are lots of ways of communication in that mostly useful and first preference is given to the social networks. [20,22,23,24,25].

\section{CONCLUSIONS}

The principle objective of this have a look at was to analyze the usage of social networks as a verbal exchange device among a teacher and students.

Increasingly instructors use social networks of their coaching exercise because the manner of communique with their students, so this could be the primary purpose why the scientific network is interested by trainer-scholar interaction difficulty solution in social networks inside the college sphere. In the university field, Vkontakte is the most popular and most used social network in Russia.

Taking into consideration the most of studies is done on the analysis which is related to the iteration frequency of social networks, in between educator and a student. The tool academics and students can be generalized when the utilization of social networks as communication. These thing of change is depend upon the communication between teacher and through social networks and it will depends on every teacher and student. Due to this academics will use social networks as a first preference in any academic platform. However the student cannot force to use them as a tool for communication with academics, since every student features a bound plan concerning the utilization of social networks within the educational field, as some students could feel uncomfortable or think about inappropriate to speak with their academics through social networks. From the purpose of read of the explanations why academics and students communicate with the help of social networks, and they can use they use tutorial functions for communication with devices. Therefore, academics ought to use social networks because the tools to speak with their students for learning-related problems. Therefore, the interaction of an educator and a student through social networks ought to be as skilled as doable.

The most frequent use of Vkontakte social network as a communication explained

tool is

is


its quality among tykes. conjointly WhatsApp may

be enclosed here, that is most typically used traveller. The most frequent use of Vkontakte social network as a communication tool is explained by its popularity among young people. Also WhatsApp can be included here, which is most commonly used messenger.

Using social networks because the means of communication between teachers and students varies, in particular depending on the perception of the challenge. but, there are clear differences related to the educational direction: amongst older guides, communication between instructors and college students in social networks is greater appropriate than among more youthful ones. this does not imply that teachers need to be careful or must not have interaction with inexperienced persons students thru social networks, however instructors should usually provide an explanation for the reasons of communique with their college students through social networks on the way to lessen discomfort.

Regarding the information that the teachers and students always publish their online profile socially, both the teacher and the student have their own opinions about each other in accordance with the content of their profiles. In the many views if teacher publish their person data on social sites then it will affect their credibility in education and so teachers should be careful of all information that they are sharing publically. As for requests for friendship between teachers and students, both teachers and students prefer not to become friends. There are many reasons for doing this is that education person cannot show there person life in social media as they are connected with academics. As the student are known to social sites they use personally it is better to do all things confidentiality. Make the proper communication with all students without any violence. In this sense, teachers should always respect the privacy of their students and avoid behavior that could disrupt their personal lives during interaction through social networks.

\section{SUMMARY}

The result which is analyzed by studies is propose to continue the analysis of communication between a teacher and a student in social networks at other educational levels, since most studies were focused on universities. In this paper a frequency of teacher is calculated according to social network which is depend upon multiple factors as together with age, gender, academic 12 months, to decide if there are considerable variations among them; to pick out motives or conditions wherein college students want to speak with their instructors on the issues now not associated with the educational field. To increase a variations in teacher and students the establishment of communication is enhance by social network and college students who do not speak can communicate via social things.

\section{ACKNOWLEDGEMENTS}

In this paper a process of work is done on the basis of the Russian Government Program of Competitive Growth of Kazan Federal University.

\section{REFERENCES}

1. Aygul Z. Ibatova - Iskandar G. Mukhametgaliyev. (2018). New ways of professional language thesaurus formation among students of engineering specialties. XLinguae, Volume 11, Issue 4, October 2018, ISSN 1337-8384, eISSN 2453-711X

2. Caci, B., Cardaci, M., \& Miceli, S. (2019). Development and Maintenance of Self-Disclosure on Facebook: The Role of Personality Traits. SAGE Open, 9(2), 2158244019856948.

3. Hershkovitz, A., Elhija, M. A., \& Zedan, D. (2019). WhatsApp Is the Message: Out-of-Class Communication, Student-Teacher Relationship, and Classroom Environment. Journal of Information Technology Education, 18.

4. Chandler, P., \& Redman, C. (2012). Teaching teachers for the future Modelling and exploring immersive personal learning networks. Australian Computers in Education Conference.

5. Williams, P. (2005). Lessons from the future: ICT scenarios and the education of teachers. Journal of Education for Teaching, 31(4), 319-339.

6. Çevik, Y. D., Çelik, S., \& Haşlaman, T. (2014). Teacher training through social networking platforms: A case study on Facebook. Australasian Journal of Educational Technology, 30(6).

7. Facundo FROMENT, Alfonso Javier GARCÍA GONZÁLEZ, Rocío BOHÓRQUEZ The Use of Social Networks as a Communication Tool between Teachers and Students: A Literature Review TOJET: The Turkish Online Journal of Educational Technology - October 2017, volume 16 issue 4

8. Aydin, S. (2014). Foreign Language Learners' Interactions with their Teachers on Facebook. System, 42, 155-163. doi:10.1016/j.system.2013.12.001

9. Smith, E. E. (2016). "A Real Double-edged Sword:" Undergraduate Perceptions of Social Media in their Learning. Computers \& Education, 103, 44-58. doi:10.1016/j.compedu.2016.09.009

10. Abella, V., \& Delgado, V. D. (2015). Aprender a usar Twitter y usar Twitter para aprender. Profesorado, Revista de Currículum y Formación del Profesorado, 19(1), 364-378. Retrieved from https://recyt.fecyt.es/index.php/profesorado/article/view/41046/23330

11. Mardani, M., \& Fallah, R. Comparison of Financial Leverage Ratio before and after the Use of Off-Balance Sheet Financing in Firms Listed in the Tehran Stock Exchange. Dutch Journal of Finance and Management, 2(2), (2018). 53. https://doi.org/10.29333/djfm/5829

12. Barreto, D. M., \& Alturas, B. Quality-in-use app evaluation: case of a recruitment app for Portuguese SMEs. Quality-in-use app evaluation: case of a recruitment app for Portuguese SMEs, (1). (2018).

13. Radhy, Z. H. Application of Multiply Regression Linear Model and New Technology Method in Estimating Learning and Education of Students. International Electronic Journal of Mathematics Education, 14(1), (2019). 87-90. https://doi.org/10.12973/iejme/3978

14. Merkibayev, T., Seisenbayeva, Z., Bekkozhanova, G., Koblanova, A., \& Alikhankyzy, G. Oppositions in the conceptual and linguistic category of time. Opción, 34(85-2), (2018). 116-148. 